ppi $201502 Z U 4645$

Esta publicación cientifica en formato digital es continuidad de la revista impresa ISSN-Versión Impresa 0798-1406 / ISSN-Versión on line 2542-3185Depósito legal pp

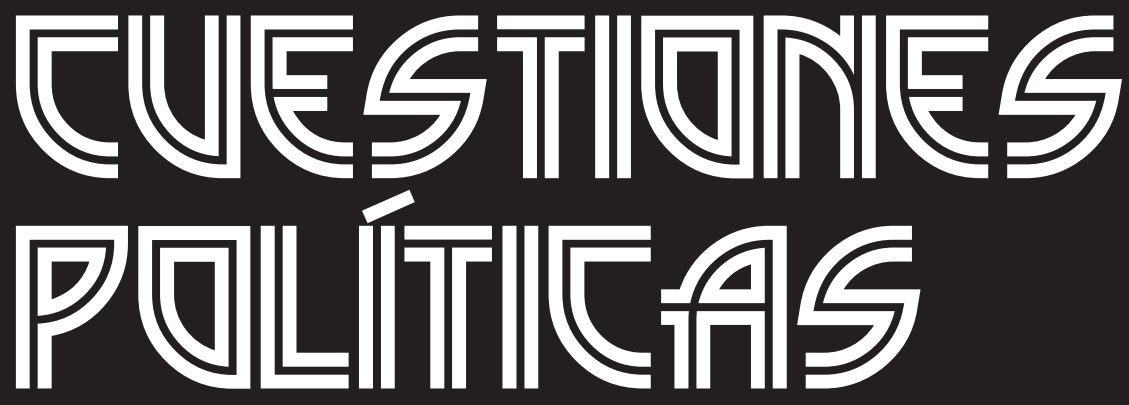

Instituto de Estudios Políticos y Derecho Público "Dr. Humberto J. La Roche' de la Facultad de Ciencias Jurídicas y Políticas de la Universidad del Zulia Maracaibo, Venezuela
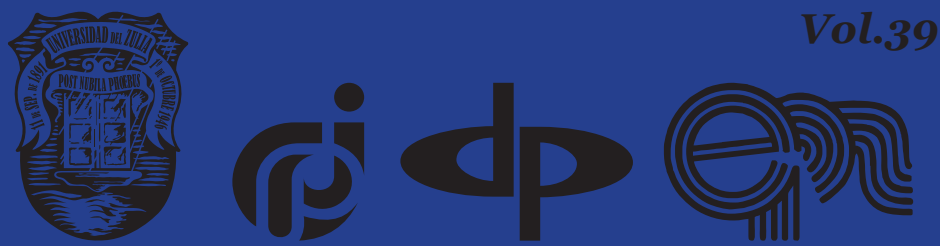


\title{
Realization of the right to free movement under quarantine conditions: practice of the European Court of Human Rights
}

\author{
DOI: https://doi.org/10.46398/cuestpol.3968.05
}

\author{
Anzhelika Krusian * \\ Vadym Tsiura ** \\ Boris Perezhniak *** \\ Roman Sabodash **** \\ Lyudmila Kazakova *****
}

\section{Abstract}

Under uncertain conditions, the introduction of a state of emergency and quarantine measures, the scope of human rights may be subject to state interference and some rights cannot be exercised at all. The aim of the work is to examine the problem of the exercise of the right to freedom of movement and personal integrity in the context of COVID-19 through the practice of the European Court of Human Rights ECTHR. The theme of the study is the social relations that arise in the exercise of the right to freedom of movement and personal integrity in the COVID-19 pandemic. Research methods are the dialectical method, the method of system analysis, synthesis, induction, deduction, modeling, comparison, generalization, and formalization. As a result of the study, the problems of the realization of the right to freedom of movement and personal inviolability in COVID-19 were analyzed through the prism of ECtHR decisions. The international experience of regulating the right to circular under quarantine conditions was clarified and suggested ways to solve this problem to protect human dignity.

* Doctor of Legal Science, Professor, Head of the Department of Constitutional, Administrative and International Law of the Kyiv Institute of Intellectual Property and Law. ORCID ID: https://orcid. org/oooo-ooo1-6437-2864. Email: 370235@ukr.net

** Doctor of Legal Science, Professor of Civil Law Department of Taras Shevchenko National University of Kyiv. ORCID ID: https://orcid.org/oooo-0002-2731-9930. Email: 370235@ukr.net

*** Doctor of Legal Science, Professor of Constitutional Law Department of National University “Odesa Law Academy" Honored Lawyer of Ukraine, Academician of the National Academy of Sciences of Higher Education of Ukraine. ORCID ID: https://orcid.org/oooo-00o2-4096-0861. Email: perezhnyak@ gmail.com

**** Ph. D., Associate Professor of Civil Law Department of Taras Shevchenko National University of Kyiv. ORCID ID: https://orcid.org/oooo-0o01-5707-1107. Email: romansabodash@knu.ua

***** Ph. D., Associate Professor of International Politics Department of Uzhorod National University. ORCID ID: https://orcid.org/oooo-ooo1-7529-9543. E-mail: Luda.kazakova@uzhnu.edu.ua 
Anzhelika Krusian, Vadym Tsiura, Boris Perezhniak, Roman Sabodash y Lyudmila Kazakova

Keywords: realization of human and civil rights and freedoms; ECtHR practice; freedom of movement; personal inviolability; Covid-19 pandemic.

\section{Realización del derecho a la libre circulación en las condiciones de cuarentena: práctica del tribunal europeo de derechos humanos}

\section{Resumen}

En condiciones de incertidumbre, la introducción de un estado de emergencia y medidas de cuarentena, el alcance de los derechos humanos puede estar sujeto a la interferencia del Estado y algunos derechos no pueden ejercerse en absoluto. El trabajo tiene como objetivo estudiar el problema del ejercicio del derecho a la libertad de circulación y la integridad personal en el contexto del COVID-19 a través de la práctica del Tribunal europeo de derechos humanos TEDH. El tema del estudio son las relaciones sociales que surgen en el ejercicio del derecho a la libertad de movimiento y la integridad personal en la pandemia de COVID-19. Los métodos de investigación son el método dialéctico, el método de análisis de sistemas, síntesis, inducción, deducción, modelado, comparación, generalización y formalización. Como resultado del estudio, se analizaron los problemas de la realización del derecho a la libertad de movimiento y la inviolabilidad personal en COVID-19 a través del prisma de las decisiones del TEDH. Se aclaró la experiencia internacional de regular el derecho a la circular en condiciones de cuarentena y se sugirieron formas de solucionar este problema para resguardo de la dignidad humana.

Palabras clave: realización de los derechos humanos; práctica del TEDH; libertad de movimiento; inviolabilidad personal; pandemia de COVID-19.

\section{Introduction}

The spread of the Covid-19 pandemic has changed people's lives. People began to travel less, visit crowded places, and, generally, move around. Such activities in November 2020 did not take place voluntarily but as a result of the adoption of a number of legislative acts. In order to ensure the security of the state border and to prevent the spread of coronavirus infection, each state has adopted regulations that have significantly affected the movement of its inhabitants and citizens. 
In general, given the growing role of civil society institutions in many countries, it is important to study the issue of legislative provision of human and civil rights and freedoms, among which the right to freedom of movement occupies a special place. Movement is a major element of freedom, self-determination, and a necessary condition for the exercise of many other rights and freedoms.

Different countries regulate the issue of restriction of movement in emergencies, including the Covid-19 pandemic, which necessitates the analysis of theoretical aspects of legal regulation of this right: its concept and content, compliance of Ukrainian legislation on this issue with the provisions of international human rights law, consider the experience of other states on the constitutional regulation of this right and the content of bills on the right to freedom of movement in Ukraine, explore the possibility of restricting this right, and to analyze the case-law of the European Court of Human Rights (hereinafter - ECtHR) on this issue.

\section{Analysis of recent research}

At present, the question of the implementation of constitutional rights and freedoms of man and citizen in the context of Covid-19 is just beginning to be studied by scientists and is extremely relevant.

To study the problematic aspects of the exercise of the right to freedom of movement and personal inviolability, the works of such scholars, lawyers, and judges as Buchkivska (2013), Vlasenko (2020), Drozdov (2020), Egorova (2020), Kokhanovska (2015), Myshchak (2020), Sukmanova et al. (2020), Chervonenko (2020), and Shutko (2020) were analyzed. As it can be seen, in order to write relevant work, we used the most recent articles, research and publications.

Firstly, it should be noted, that Buchkivska (2013) investigated the restriction of individual freedom and inviolability during criminal proceedings, taking into account the case-law of the European Court of Human Rights.

Moreover, in her work, Vlasenko (2020) drew attention to the fact that Kyiv did not limit the effect of the Convention on Human Rights due to the epidemic. Thus, the author notes that under quarantine, which provides for several restrictions for citizens, only eight member states of the Council of Europe have suspended some articles of the European Convention on Human Rights and Ukraine is not among them.

Drozdov (2020) analyzed the criteria for ensuring human rights under Covid-19. The author drew attention to the most popular arguments about the illegality of restrictions on freedom of movement, which is that restrictions on constitutional human rights and freedoms are permissible 
Anzhelika Krusian, Vadym Tsiura, Boris Perezhniak, Roman Sabodash y Lyudmila Kazakova 106

only in a state of war or emergency. Thus, Drozdov (2020) drew attention to Part 1 of Article 64 of the Constitution and the fact that rights and freedoms may be restricted in the cases provided for by it. According to Article 33 of the Constitution, freedom of movement may be restricted by law. As to the author, the thesis about the illegality of restrictions and the possibility of imposing them only in a state of emergency or martial law can be questioned. Regarding the proportionality and social necessity of the restriction, the author brings attention to the fact that to be constitutional, the restriction of a right or freedom must not only comply with the law, but also be proportional and socially necessary.

Besides, Kokhanovska (2015) analyzed the problems of exercising the right to freedom of movement in Ukraine, as well as the case-law of the European Court on these issues. She examines the provisions of the Civil Code of Ukraine and the Constitution of Ukraine and the stipulations of international instruments the conditions under which these restrictions are allowed, as well as the right to freedom of movement and the right to free choice of residence are analyzed on practical examples.

Alternatively, Kravets (2020) studied in detail the interference in various human rights during the pandemic. Then, Myshchak (2020) explained the legality of the introduction of quarantine in Ukraine and the compliance of restrictive measures with constitutional guarantees for the protection of citizens' rights. It should be noted that Sukmanova et al. (2020) analyzed the strengthening of quarantine measures, namely the restriction of free movement of citizens. Furthermore, Chervonenko (2020) investigated whether quarantine restrictions in Ukraine contradict the Constitution. Shutko (2020) summarized, in his work, all the legislative changes caused by coronavirus disease. What is more, Egorova (2020) emphasizes on how Covid-19 mobilizes and how civil society adapts to change.

Analytical materials on the researched topic from the sites of law firms and public platforms were also used in the work.

The above analysis of the literature confirms that the problem of exercising the right to freedom of movement and personal integrity through the practice of the ECtHR in quarantine is insufficiently studied, which indicates the need for comprehensive research.

\section{Methodology}

The study of the implementation of the right to freedom of movement and personal integrity in Covid-19 through the practice of the ECtHR used research methods such as dialectical method, method of system analysis, synthesis, induction, deduction, modeling, comparison, generalization, and formalization. 
Primarily, the dialectical method made it possible to analyze the dynamics of the ECtHR's decisions on the exercise of the right to freedom of movement and personal integrity and their significance in the context of the need to ensure human and civil rights and freedoms during the quarantine.

Further, the method of comparison was used to study and establish differences between the exercise of the right to freedom of movement and personal inviolability in normal conditions and the conditions of Covid-19, as well as between the implementation of the studied right in quarantine in Ukraine and other countries.

Moreover, the generalization allowed us to identify key issues that reflect the realization of human and civil rights and freedoms in the context of Covid-19. It is also allowed to analyze the necessary changes for the successful implementation of the right to freedom of movement and personal integrity in Ukraine.

The method of abstraction allowed to imaginatively divert attention from the insignificant properties and connections of the exercise of the right to freedom of movement and personal inviolability. It helps to investigate the state of observance and realization of constitutional human and civil rights and freedoms in Ukraine under normal conditions and various restrictions.

What is more, the method of formalization allowed to reflect the problems of exercising the right to freedom of movement and personal inviolability through a formal examination of ECtHR decisions.

Using the method of systematic analysis, it became possible to divide the problem of exercising the right to freedom of movement and personal inviolability through the prism of the ECtHR decisions into its parts, namely: problematic aspects of the implementation of the Convention in Ukraine, problematic issues of legislative enshrinement implementation and problematic issues of application of the case-law of the European Court of Human Rights in Ukraine. The synthesis, in turn, made it possible to unite the individual aspects of social relations that arise, change, and cease during the exercise of the right to freedom of movement and personal inviolability as a whole.

The method of induction allowed us to draw conclusions on the research topic through the general problems of realization of human and civil rights and freedoms in a pandemic. The method of deduction made it possible to conclude by analyzing the peculiarities of the exercise of the right to freedom of movement and personal integrity in quarantine.

Besides, the method of analogy allowed us to analyze the realization of the right to freedom of movement and personal inviolability with the help of knowledge about how other rights are realized in the same conditions in Ukraine. 
Anzhelika Krusian, Vadym Tsiura, Boris Perezhniak, Roman Sabodash y Lyudmila Kazakova 108

Realization of the right to free movement under quarantine conditions: practice of the European Court of Human Rights

Finally, the method of modeling allowed to model situations in which the rights and freedoms of citizens will be realized in the conditions of quarantine in full or with the minimum restrictions which will be justified by public necessity.

When writing the article, the current legislation and case-law were analyzed.

\section{Presentation of key research findings \\ 3.1. International experience in ensuring the right to movement and personal integrity}

The right to movement and personal integrity is one of the rights, affected by state interference during the quarantine. The Convention for the Protection of Human Rights and Fundamental Freedoms (United Nations, 1950) (hereinafter - the Convention) provides for the interpretation of the above rights, and the decision of the European Court of Human Rights (hereinafter - the ECtHR) reflects the mechanism of protection of rights guaranteed by the Convention. The basis of the general the principles of EU law are the priority of the rights of the individual, enshrined in the European Convention, which takes into account the constitutional traditions of European countries.

Concerning the international experience of exercising the right to movement and personal integrity, it should be noted that foreign governments have imposed many restrictions on ordinary life in the member states of the Council of Europe. These restrictions necessarily affect the exercise of rights and freedoms under the Convention, regardless of whether their imposition was accompanied by a notification under Article 15 of the Convention (United Nations, 1950: article 15) on the waiver of obligations by countries such as Armenia, Estonia, Georgia, Latvia, the Republic of Moldova and Romania. However, the undoubted existence of a certain obligation to act to protect life and physical integrity is necessary when assessing the compatibility of possible restrictions on other rights and freedoms. Thus, the articles of the Convention stipulate that the prevention of the spread of infectious diseases is one of the grounds for depriving a person of his or her liberty.

In Enhorn v. Sweden (European Court of Human Rights, 2005), the ECtHR found that it must also be demonstrated that the spread of an infectious disease is dangerous to the health or safety of the population and that the detention of an infected person is the last resort to prevent the spread of the disease because less severe measures were recognized and found insufficient to protect the interests of society. In addition, whenever these criteria are no longer met, the grounds for deprivation of liberty cease to exist. 
Restrictions must be necessary for a democratic society and thus proportionate to the legitimate aim pursued. However, in only one case, Kuimov v. Russia (European Court of Human Rights, 2009), the ECtHR emphasizes that the restriction should be a temporary measure that should be lifted as soon as circumstances permit.

However, in the case of Covid-19, it should be borne in mind that the ECtHR considers significant interference with the law when the State has taken action in response to "the existence of an exceptional crisis without precedent”.

It is necessary to determine whether the establishment of the peculiarities of movement is a deprivation of liberty or only interference with the freedom of movement. The ECtHR notes that to determine whether a person has been deprived of his or her liberty, it is important to analyze the situation and to consider the type, duration, consequences, and manner of the measure, as the difference between deprivation and restriction of liberty is character or essence.

Therefore, it is essential to prove the need to stop the spread of coronavirus and whether the measure was adopted only when other smaller restrictions did not apply, as well as whether it was not kept longer than was necessary to achieve the goal. Restricting access to certain places, districts, or parts of the country and even to places of residence is considered an interference with the right to freedom of movement.

Currently, there have been changes in the movement of Ukrainians. Thus, during the period of quarantine restrictions, the movement of Ukrainians changed as follows (Table 1).

\begin{tabular}{|l|l|}
\hline Travel points & $\begin{array}{l}\text { Change in indicators from the } \\
\text { control value during the Covid-19 } \\
\text { pandemic }\end{array}$ \\
\hline Retail and recreation & $-11 \%$ \\
\hline Grocery stores and pharmacies & $+5 \%$ \\
\hline Parks & $+3 \%$ \\
\hline Transit stations & $-6 \%$ \\
\hline Workplaces & $-27 \%$ \\
\hline Residential & $+2 \%$ \\
\hline
\end{tabular}

Table 1. The changes in the movement of Ukrainians. Data provided by the Google (2020).

As for the experience of foreign countries in solving the problem of realization of rights and freedoms, it was noted that several member states are deviating from their obligations. Latvia's resignation also implies a possible extension of imprisonment. Derogations from the obligations of 
Armenia, Estonia, and Latvia include a ban on entry to all or some persons who are not citizens or legal residents. Armenia prohibits its citizens from leaving the country except for cargo, and a similar result will be achieved by Latvia's order to close international passenger traffic, as well as the requirement to cancel, postpone and not plan all business trips to countries affected by Covid-19, and appeals to refuse from traveling abroad. In their waivers, both the Republic of Moldova and Romania impose indefinite restrictions on freedom of movement. The ability of a person to leave any country, including his or her own, is guaranteed by Article 2 of Protocol No. 4 to the Convention for the Protection of Human Rights and Fundamental Freedoms (United Nations, 1963: article 2) but may be subject to restrictions, including health care, if necessary in a democratic society.

The European Union has provided travel recommendations and called for restrictions on "minor travel" - that is, travel other than travel or trips to a pharmacy, hospital, shop, or work. The latter is the most important: the $\mathrm{EU}$ and most EU countries believe that restrictive measures can last for a significant period of time - from several months to two years, and therefore should not lead to significant economic problems and social cataclysms. To do this, employers need to determine which employees are present and for how long is critical to maintaining economic activity. Besides, the EU has introduced restrictions on "minor travel" to the Schengen area. Thus, within 30 days, foreign nationals will be able to enter the EU only in exceptional cases. Each country decides individually on measures to control the coronavirus. These restrictions apply to all those who remain in its territory for the period of quarantine.

All mass events are banned in Austria; it is forbidden to gather in groups of more than five people; all bars and restaurants are closed; entry restrictions have been introduced. There are no restrictions on public transport in the country yet.

Estonia has imposed a state of emergency, quarantined, and banned foreigners from entering. At the same time, in Spain, people can go out only to buy medicine and food, go to work if there is an urgent need, and go to medical facilities and banks. Trips to care for children or the elderly are also allowed. You can leave the house to walk your pet. Some rent out their pets for this purpose, others go outside with toys. Spain has closed its borders to foreigners and restricted travel within the country. In Serbia, people over the age of 65 are banned from going outside. For older people living in villages and towns with a population of less than 5,000 , the age barrier is slightly higher - the ban applies to anyone over 70 years of age (ICPS: International Centre for Policy Studies, 2020).

Now, it will be appropriate to pay attention to changes in movement in foreign countries (Estonia) (Table 2) and compare it with the experience of Ukraine. 


\begin{tabular}{|l|l|}
\hline Travel points & $\begin{array}{l}\text { Change in indicators from the } \\
\text { control value during the Covid-19 } \\
\text { pandemic }\end{array}$ \\
\hline Retail and recreatjon & $-12 \%$ \\
\hline Grocery stores and pharmacies & $+1 \%$ \\
\hline Parks & $+3 \%$ \\
\hline Transit stations & $-23 \%$ \\
\hline Workplaces & $-16 \%$ \\
\hline Residential & $+7 \%$ \\
\hline
\end{tabular}

Table 2. Mobility changes in Estonia. Data provided by the Google (2020).

Thus, it can be seen from the Figure 1 (in comparison with the domestic legislator), in Estonia, new restrictive legislative norms work for the benefit of the population more effectively.

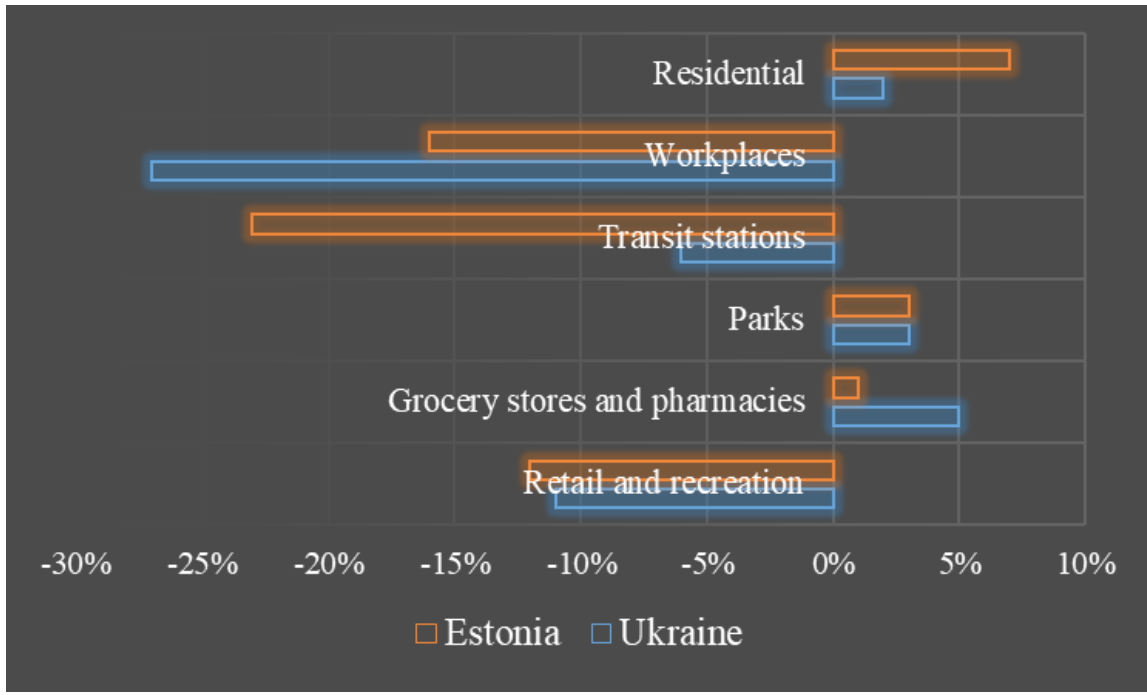

Figure 1. Mobility changes in Ukraine and Estonia: Comparison Chart. Own elaboration.

It should be noted that the extent of any restrictions imposed in response to a pandemic threat will be considered an unjustified interference with the rights and freedoms under the Convention - whether or not there is a reference to a waiver, will depend in particular on the specific situation in the Member State, as well as their degree and duration. 
Anzhelika Krusian, Vadym Tsiura, Boris Perezhniak, Roman Sabodash y Lyudmila Kazakova

\subsection{National legislation concerning the right to movement}

According to the provisions of the Constitution of Ukraine (1996), Ukraine is a sovereign and independent, democratic, social, legal state, and man, his life and health, honor and dignity, inviolability, and security are recognized in Ukraine as the highest social value. Human rights and freedoms and their guarantees determine the content and direction of the state, which is responsible to man for his activities; affirmation and protection of human rights and freedoms is the main duty of the state. The state is responsible to the person for the activity. The rights and freedoms of man and citizen are inalienable and inviolable. Constitutional human rights and freedoms are guaranteed and cannot be revoked.

Art. 29 of the Constitution of Ukraine (1996), everyone has the right to liberty and security of person. Exceptions to this rule are contained in the Constitution itself. Moreover, the article 33 of the Constitution of Ukraine states that everyone is guaranteed freedom of movement. Exceptions can be established only by law, not by-laws.

Under Article 29 of the Law of Ukraine "On Protection of the Population from Infectious Diseases" (2000: article 29) and the Law of Ukraine "On National Security of Ukraine" (2018) in order to prevent the spread of acute respiratory disease Covid-19 caused by coronavirus SARS-CoV-2, the Cabinet of Ministers of Ukraine by Resolution of March 11, 2020, No 211 "On prevention of the spread of acute respiratory disease Covid-19 caused by coronavirus SARS-CoV-2" (2020) (with further changes) throughout Ukraine quarantine (On the establishment of quarantine to prevent the spread of acute respiratory disease Covid-19 caused by coronavirus SARSCoV-2 in Ukraine and the stages of mitigation of anti-epidemic measures: Resolution, 2020).

By the provisions of the above resolution, several prohibitions have been established. Thus, it is forbidden:

- To be in public places without wearing personal protective equipment.

- Relocation by a group of persons of more than two persons, except in cases of official necessity and accompaniment of persons under 14 years of age.

- Unaccompanied persons in public places under the age of 14 .

- Visiting parks, squares, sports and children's playgrounds, recreation areas, forest parks and coastal areas, except for walking pets by one person and in case of business necessity.

- holding mass events. 
- Being on the streets without identity documents confirming citizenship or its special status; arbitrarily leave places of observation (isolation), etc. (On the establishment of quarantine to prevent the spread of acute respiratory disease Covid-19 caused by coronavirus SARS-CoV-2 in Ukraine and the stages of mitigation of anti-epidemic measures: Resolution, 2020).

Such restrictions largely affect the scope of human rights and freedoms in Ukraine. Therefore, given the restrictions, it is important to analyze in more detail the problems of exercising the right to freedom of movement and personal integrity in Covid-19, their legality. Further, attention should be paid to the ECtHR's position on state protection, to explore how ECtHR decisions are used by Ukrainian courts and model possible tools for addressing human rights and fundamental freedoms.

As already mentioned, inviolability and human security are recognized in Ukraine as the highest social value. The combination of the concepts of "freedom" and "personal integrity" is not accidental. They have a history. Freedom is the human right to do everything permitted by law. Under such conditions, a person can have complete freedom, be free to choose a certain course of action within the existing laws of the state. If a society does not ensure the realization of human rights and freedoms, such a society cannot be considered democratic.

Under modern conditions, this right is enshrined in international law and national legislation of Ukraine.

The Constitution of Ukraine stipulates that the Convention for the Protection of Human Rights and Fundamental Freedoms ratified by Ukraine is part of national legislation.

According to Art. 17 of the Law of Ukraine "On Enforcement of Judgments and Application of the Case Law of the European Court of Human Rights" (2006: article 17), courts use the Convention and the caselaw of the European Court of Human Rights as a source of law.

The provisions of Article 19 of the Convention provide that, for States Parties to comply with the Convention, their obligations under the Convention and its Protocols, a European Court of Human Rights shall be established permanently. The Contracting Parties undertake to comply with the final decisions of the Court in any case to which they are parties.

That is, Ukraine's ratification of the Convention has obliged our state to create reliable and effective mechanisms for enforcing ECtHR decisions and applying the case law of this court as a source of law. In the case-law of the ECtHR, the notion of "freedom and personal integrity" is declared primarily in decisions on violations of Article 5 of the Convention, which enshrines a fundamental human right, namely the protection of everyone 
from arbitrary interference by the State with his right to liberty. Any deprivation of liberty, as the Court notes, must be carried out not only under the basic procedural rules of national law but also following the purpose of Article 5, i.e. to protect a person from the arbitrariness of the authorities.

Under Article 5 of the Convention, the right to liberty and security of a person includes freedom from arbitrary arrest and detention, imprisonment only based on "law", the right to be informed of the reasons for arrest, the right to judicial review of arrest and detention, and the right to challenge the legality of arrest and detention, the right to compensation for illegal actions.

At the same time, proclaiming the "right to liberty", the Convention understands personal freedom as the physical freedom of a person.

\subsection{The right to movement and personal integrity in ECTHR decisions}

Consider how the right to movement and personal integrity is ensured in ECtHR decisions. Thus, the judgments of the ECtHR pursue the general purpose of the Convention - to ensure that no one may be deprived of this liberty arbitrarily (judgment in Engel and Others v. The Netherlands (1976)).

Not all types of deprivation of liberty are prohibited in the Convention. The right to liberty and security of a person within the meaning of the Convention shall be construed as protecting against any procedural or substantive infringement of personal freedom by public authorities. To ensure the rule of law, national authorities are obliged to comply with domestic law, and there should be no abuse of power or dishonesty in the actions of the state.

Thus, in the judgment in Winterwerp v. The Netherlands (European Court of Human Rights, 1979), the ECtHR emphasized that the notion of "lawful" encompasses both procedural and substantive rules. It somewhat coincides with the general concept of "procedure established by law". Compliance with domestic law is directly the responsibility of the State, and the Convention allows the ECtHR to decide whether domestic law has been complied with. Arbitrary deprivation of liberty carried out in violation of the law and without observance of the procedures and guarantees provided for by national law may lead to a violation of Article 5 of the Convention.

The ECtHR noted that the current legislation of Ukraine is imperfect, and it is necessary to adhere to the principle of legal certainty. Thus, in the judgment in Yeloyev v. Ukraine (European Court of Human Rights, 2008), the ECtHR considers that the absence of clearly worded provisions contradicts the criterion of "predictability of the law" for Article $5 \S 1$ of the Convention. 
The ECtHR in Garkavyi v. Ukraine (European Court of Human Rights, 2010) stated that a person may not or may not be deprived of his liberty, except as provided for in the Convention. This list of exceptions is exhaustive, and only a narrow interpretation of these exceptions is in line with the purpose of this provision, which is to ensure that no one is arbitrarily deprived of his liberty. Thus, the right to freedom and security of a person is not absolute and may be limited, but only on the grounds and in the manner clearly defined by law.

Article 3 of the Law of Ukraine "On Freedom of Movement and Free Choice of Residence in Ukraine" (2003) stipulates that freedom of movement is the right of a citizen of Ukraine, as well as a foreigner and stateless persons legally staying in Ukraine, to move freely and without hindrance at will in the territory of Ukraine in any direction, in any way, at any time, except for the restrictions established by law.

Thus, the spread of the Covid-19 pandemic has led to several restrictive measures that have restricted the rights of citizens, foreigners, and stateless persons in Ukraine, and the right to freedom of movement and personal integrity cannot be fully realized. However, such restrictions can be considered justified if their public necessity is proved, the legal procedure for imposing restrictions is followed, and such restrictions do not contradict the provisions of the Constitution, the Convention, and other legislative acts.

\section{Discussion of the obtained results}

As a result of the study, the problems of realization of the right to freedom of movement and personal inviolability in the conditions of Covid-19 through the practice of the European Court of Human Rights were analyzed and the following conclusions were made.

1. The Convention seeks to ensure that no one shall be deprived of his liberty arbitrarily.

2. The Convention does not prohibit all kinds of restrictions but restricts rights not in accordance with the law and without following the procedures and guarantees provided by national law.

3. The ECtHR considers that clear provisions on restrictions on freedom of movement should be provided for in domestic law.

4. Restrictions must be necessary and thus proportionate to the legitimate aim pursued.

5. The restriction shall be a temporary measure which must be terminated as soon as circumstances permit. 
Anzhelika Krusian, Vadym Tsiura, Boris Perezhniak, Roman Sabodash y Lyudmila Kazakova

\section{Conclusions}

Thus, the analysis of the ECtHR's practice on the problematic issues of exercising the right to freedom of movement and personal integrity in Covid-19 and the ECtHR's practice concluded that in quarantine these rights may be restricted, but such restrictions cannot be imposed arbitrarily.

First of all, restrictions on human rights by the state must be proportionate to the legitimate aim. In the case of a coronavirus pandemic, the legitimate aim is to curb the spread of the disease. At the same time, the governments of the world must use all possible measures to implement such deterrence, and only as a last resort - to restrict human rights. Moreover, such restrictions on human rights must be clearly defined in time and cannot be indefinite. In the event of litigation with citizens, the state must prove the justification for the application of restrictions and whether a certain restrictive measure was applied only when other minor restrictions did not apply, and whether it was maintained longer than was necessary to achieve the goal.

An important aspect that can negatively affect the state of protection of human rights in different countries around the world during a pandemic is the right of the state in some cases to derogate from the provisions of the Convention. In particular, the Convention provides for the possibility for a State party to derogate from its obligations under the Convention during an emergency (Article 15). Thus, in the event of war or other public danger threatening the life of a nation, any State Party may take measures which derogate from its obligations under this Convention only to the extent required by the urgency of the situation and provided that such measures do not conflict with its other obligations under international law.

As of mid-2020, the States Parties to the Convention (including Latvia, Romania, Armenia, the Republic of Moldova, Estonia, Georgia, Albania, Northern Macedonia, Serbia, and San Marino) had already notified the Secretary-General of the Council of Europe of their decision to apply the provisions of Art. 15 of the Convention in the context of the Covid-19 pandemic. Some States subsequently reported the extension of the derogation and / or its termination with a full return to the provisions of the Convention. In turn, Ukraine did not make such statements.

Thus, this study is an attempt to analyze the first decisions of the ECtHR on human rights violations during the coronavirus pandemic. However, it is currently not possible to predict the extent of the pandemic infringement cases. The virus continues to spread across the planet, and it is not yet known what other measures the state will take to prevent it.

It is worth taking into account the duration of the formation of the caselaw of the ECtHR, as the ECtHR considers cases only after the exhaustion of all national remedies, and the consideration of cases takes some time. Therefore, it is too early to analyze the ECtHR's practice of violating 
Convention rights as a result of measures taken by States to prevent Covid-19 or to draw conclusions about the relevant positions of the ECtHR. However, given the use of ECtHR case law by Ukrainian courts as a source of law and the binding nature of ECtHR judgments in cases against Ukraine, the Ukrainian legal community should monitor possible ECtHR decisions in pandemic cases.

Undoubtedly, the problem of restricting the right to move requires further research, especially given the intensive formation of the caselaw of the European Court of Human Rights in this area in the future. In particular, it is very crucial to study the mechanisms of restoration of limited human rights and freedoms, because all the possessions of modern human civilization, one of the most important of which is the right to free movement, must be preserved.

\section{Bibliographic References}

BUCHKIVSKA, Vladyslava. 2013. "Restrictions on individual liberty and inviolability in criminal proceedings: a new criminal procedure law taking into account the case law of the European Court of Human Rights" In: Scientific notes of Lviv University of Business and Law. Vol. 10, pp. 153-158. Available online. In: http://nbuv.gov.ua/UJRN/ Nzlubp_2013_10_36. Consultation date: 11/08/2019.

CHERVONENKO, Vitalii. 2020. Quarantine in Ukraine: do the new prohibitions of the Constitution contradict it? BBC. Available online. In: https://www. bbc.com/ukrainian/features-52186556. Consultation date: 20/05/2020.

DROZDOV, Oleksander. 2020. Covid-19 and human rights: ECtHR criteria. ECHR: Ukrainian Aspect. Available online. In: https://www.echr.com. ua/covid-19-ta-prava-lyudini-kriteri\%D1\%97-yespl/. Consultation date: 11/04/2020.

EGOROVA, Anna. 2020. Covid-19 mobilizes: how civil society adapts to change. Media Detector. Available online. In: https://detector.media/infospace/ article/177382/2020-05-22-covid-19-mobilizue-yak-gromadyanskesuspilstvo-adaptuetsya-do-zmin/. Consultation date: 20/04/2020.

EUROPEAN COURT OF HUMAN RIGHTS. 1976. Engel and others v. The Netherlands: Judgment Available online. In: http://hudoc. echr.coe.int/app/conversion/pdf/?library =ECHR\&id=00157479\&filename $=$ 001-57479.pdf\&TID=yolhnfsryr. Consultation date: 01/10/2019. 
Anzhelika Krusian, Vadym Tsiura, Boris Perezhniak, Roman Sabodash y Lyudmila Kazakova Realization of the right to free movement under quarantine conditions: practice of the European 118 Court of Human Rights

EUROPEAN COURT OF HUMAN RIGHTS. 1979. Winterwerp v. The Netherlands: Judgment. Available online. In: https://hudoc. echr.coe.int/app/conversion/pdf?library=ECHR\&id=00173578 \&filename = W INTER WERP\% $20 \mathrm{v} . \% 2$ o THE \% 20 NETHERLANDS.pdf. Consultation date: 01/10/2019.

EUROPEANCOURTOFHUMANRIGHTS.2005.Enhornv.Sweden:Judgment. Available online. In: http://hudoc.echr.coe.int/app/conversion/ pdf/?library $=$ ECHR\&id $=001-113629 \&$ filename $=001-113629$. pdf\&TID=thkbhnilzk. Consultation date: 01/10/2019.

EUROPEAN COURT OF HUMAN RIGHTS. 2008. Yeloyev v. Ukraine: Judgment. Available online. In: http://hudoc.echr.coe.int/app/ conversion/pdf/?library $=$ ECHR\&id $=001-77201 \&$ filename $=001-77201$. pdf. Consultation date: 20/09/2019.

EUROPEAN COURT OF HUMAN RIGHTS. 2009. Kuimov v. The Russian Federation: Judgment. Available online. In: http:// hudoc.echr.coe.int/app/conversion/pdf/?library=ECHR\&id=00180945\&filename $=001-80945$.pdf\&TID $=$ ihgdqbxnfi. Consultation date: 25/11/2019.

EUROPEAN COURT OF HUMAN RIGHTS. 2010. Garkavyy v. Ukraine: Judgment. Available online. In: http://hudoc.echr.coe.int/app/ conversion/pdf/?library=ECHR\&id=001-97425\&filename=001-97425. pdf\&TID=ihgdqbxnfi. Consultation date: 11/08/2019.

GOOGLE. 2020. Find out how people move around the city amid the COVID-19 pandemic. Available online. In: https://www.google.com/covid19/ mobility/. Consultation date: 07/06/2020.

ICPS: INTERNATIONAL CENTRE FOR POLICY STUDIES. 2020. How to Fight Covid-19 in the World: options for government decisions. Available online. In: http://icps.com.ua/yak-boryutsya-z-covid-19-u-svitivarianty-uryadovykh-rishen/. Consultation date: 07/06/2020.

KOKHANOVSKA, Olena. 2015. "Problems of realization of the right to freedom of movement in Ukraine and the practice of the European Court" In: Journal of Civilization. Vol. 18, pp. 157-163. Available online. In: http://dspace.onua.edu.ua/handle/1130o/8370. Consultation date: 20/09/2019.

KRAVETS, Rostislav. 2020. Interference in human rights during a pandemic. Protocol. Available online. In: https://protocol.ua/ua/vtruchannya_v_ prava_lyudini_pid_chas_pandemii/.Consultation date: 20/05/2020. 
MYSHCHAK, Ivan. 2020. "The legality of the introduction of quarantine in Ukraine, or the question of compliance of restrictive measures with constitutional guarantees for the protection of citizens' rights" In: Constitutional process in Ukraine: political and legal aspects. Vol. 4 (72), pp. 3-9. Available online. In: http://nbuviap.gov.ua/images/ konstutyciynuy_proces/2020/4.pdf. Consultation date: 25/01/2020.

SHUTKO, Viktoriia. 2020. Coronavirus in Ukraine: everything you need to know, including the law No. 3219. Protocol. Available online. In: https:// protocol.ua/ua/koronavirus_v_ukraini_vse_shcho_vam_neobhidno_ znati/. Consultation date: 11/06/2020.

SUKMANOVA, Olena; POZYCHANYUK, Kuzma; ZAYETS, Zhanna. 2020. Strengthening quarantine measures: restriction of free movement of citizens. EBA. Available online. In: https://eba.com.ua/posylennyakarantynnyh-zahodiv-obmezhennya-vilnogo-peresuvannyagromadyan/. Consultation date: 19/04/2020.

UKRAINE LAW. 2006. On the implementation of decisions and application of the case law of the European Court of Human Rights: Law 3477-IV. Available online. In: https://zakon.rada.gov.ua/laws/show/3477-15. Consultation date: 25/09/2020.

UKRAINE. 2003. On freedom of movement and free choice of place of residence in Ukraine: Law 1382-IV. Available online. In: https://zakon.rada.gov. ua/laws/show/1382-15\#Text. Consultation date: 07/09/2020.

UKRAINE. 2018. On National Security of Ukraine: Law 2469-VIII. Available online. In: https://zakon.rada.gov.ua/laws/show/2469-19\#Text. Consultation date: 19/08/2019.

UKRAINE. 2020. On the establishment of quarantine to prevent the spread of acute respiratory disease COVID-19 caused by coronavirus SARS-CoV-2 in Ukraine and the stages of mitigation of anti-epidemic measures: Resolution 392. Available online. In: https://www.kmu.gov.ua/npas/ pro-vstanovlennya-karantinu-z-metoyu-zapobigannya-poshirennyuna-teritoriyi-ukrayini-gostroyi-respiratornoyi-hvorobi-covid-19sprichinenoyi-koronavirusom-sars-cov-i200520-392/. Consultation date: 07/09/2020.

UKRAINE. CABINET OF MINISTERS. 2020. On prevention of the spread of coronavirus Covid-19 on the territory of Ukraine: Resolution 211. Available online. In: https://www.kmu.gov.ua/npas/pro-vnesennyazmin-do-postanovi-kabinetu-ministriv-ukrm020420ayini-vid-11bereznya-2020-r-211. Consultation date: 20/06/2020. 
Anzhelika Krusian, Vadym Tsiura, Boris Perezhniak, Roman Sabodash y Lyudmila Kazakova

120

Realization of the right to free movement under quarantine conditions: practice of the European Court of Human Rights

UKRAINE. CONSTITUTION. 1996. Law, no. 254k / 96-VR. Revision of September 30, 2016, grounds - 1401-19. Available online. In: https:// zakon.rada.gov.ua/laws/show/254\%Do\%BA/96-\%Do\%B2\%D1\%80. Consultation date: 19/08/2019.

UKRAINE. LAW. 2000. On protection of the population from infectious diseases, no. 1645-III. Available online. In: https://zakon.rada.gov.ua/ laws/show/1645-14. Consultation date: 25/11/2019.

UNITED NATIONS. 1950. Convention for the Protection of Human Rights and Fundamental Freedoms. Available online. In: https://www.echr.coe. int/documents/convention_eng.pdf. Consultation date: 07.10.2019.

UNITED NATIONS. 1963. Protocol No. 4 to the Convention for the Protection of Human Rights and Fundamental Freedoms, securing certain rights and freedoms other than those already included in the Convention and in the first Protocol thereto. Available online. In: https://rm.coe. int/168006b65c. Consultation date: 25/10/2019.

VLASENKO, Viktoriia. 2020. Kyiv did not limit the Convention on Human Rights due to the epidemic. Available online. In: https://www.dw.com/ uk/kyiv-ne-obmezhuvav-diiu-konventsii-z-prav-liudyny-cherezepidemiiu/a-53023831. Consultation date: 20/04/2020. 

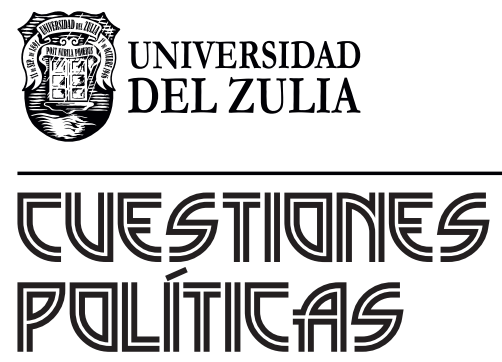

Vol.39 No 68

Esta revista fue editada en formato digital y publicada en enero de 2021, por el Fondo Editorial Serbiluz, Universidad del Zulia. Maracaibo-Venezuela 